\title{
The Effect of Remittance, GDP, Investment, and Population on Unemployment in Indonesia
}

\author{
RATNI HELIATI \\ Universitas Padjadjaran, Jl. Raya Bandung Sumedang KM. 21, Indonesia \\ email: ratniheliati@yahoo.com
}

\begin{abstract}
One of the problems exist in almost all countries is unemployment that has not been resolved perfectly. It occurs because employment cannot absorb all the job seekers who have diverse expertise, as well as domestic investment that is still unable to create new jobs. Indonesia which has an increase of population above the economic growth has not been able to alleviate unemployment so that it needs to encourage and enlarge export services. Researchers take unemployment, economic growth, and remittance as the topic of discussion, where data reveals that number of unemployed people increases very rapidly and remittances tend to be stable. The method used in this study is Ordinary Least Square (OLS) with the study location in Indonesia and using annual data (time series) from 1984 to 2016. The research results show that remittances, population growth, and economic growth have a significant positive effect on unemployment, while investment has a significant negative effect on unemployment. In the end, the problem of unemployment cannot be resolved partially but need to jointly encourage all possible variables for the solution.
\end{abstract}

Keywords: Unemployment, Remittance, Economic Growth

\section{Introduction}

Unemployment is one of the crucial problems in the world, including in Indonesia. Every citizen will try to find employment opportunities, and it is the government's responsibility to provide employment, including for less educated workers. The discussion about unemployment due to the lack of employment opportunities or even no jobs available in one country, Indonesia is included, has been discussed and reflected in Article 27 paragraph 2 of the 1945 Constitution which states that . "each citizen shall be entitled to an occupation and an existence proper for a human being'. Based on the statement, the problem of unemployment should be solved by community members with the help of government intervention, but many countries cannot afford to carry out these responsibilities. All efforts have been made to the maximum but still the majority of the available workforce is unemployed. Nevertheless, the government and the community never stop trying to alleviate unemployment until the community earns income. One of the solution is by selling services or working abroad so that they can get an income called remittance.

Some developed countries such as Korea, Malaysia, Singapore, and China have succeeded in minimizing the unemployment problems. Their secrets of success are factors of political stability, good governance, law enforcement, and fixed regulations. Foreign investors see this as an attractive opportunity to invest their capitals so that investment in those countries increases, workers can get jobs, and unemployment is solved, which ultimately have an impact on increasing economic growth. Governments in developing countries should take those countries as their model in determining the vision of the country (Lal \& Muhammad, 2010).

When the unemployment rate increases, the economy will not produce maximum output so that efforts are needed to reduce unemployment. One way is to export Indonesian labor services abroad with proceeds called remittance. Efforts to

Received: 2019-01-28, Revised: 2019-04-08, Accepted: 2019-05-29

Print ISSN: 0215-8175; Online ISSN: 2303-2499. DOI: http://dx.doi.org/10.29313/mimbar.v35i1.4396

Accredited $\mathbf{S 2}$ based on the decree No.10/E/KPT/2019 until 2024. Indexed by DOAJ, Sinta, Garuda, Crossreff, Dimensions 
reduce unemployment can be done through increasing the service trade as mentioned by (Jajang, Saefuddin, Mangku, \& Siregar, 2013) where there are policies that can be taken to reduce the number of poor people, such as increasing economic growth and education, controlling population, and transforming labor from the agricultural sector to the industrial, trade, and services. Based on the description above, this study is conducted to examine the effect of remittance from workers working abroad on the unemployment rate in the country and find out to what extent the unemployment will decline when the remittance falls by $1 \%$. However, this study only examined the effect of the total income results, not of the number of workers working abroad as shown from the data on remittances and unemployment in figure 1.

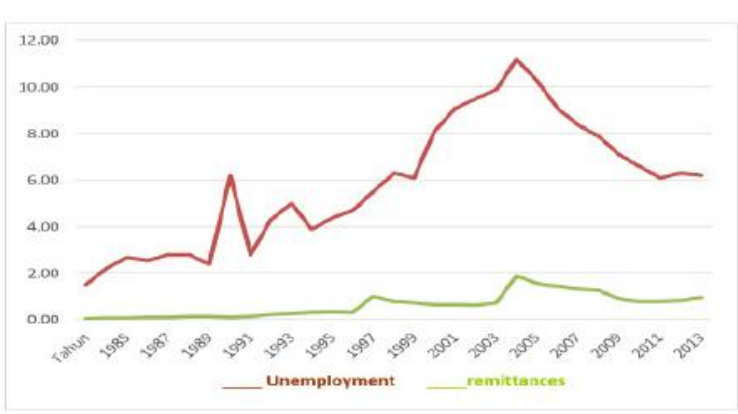

Source: World Bank, 1984-2016

Figure 1. The Level of Unemployment and Remittance

Based on figure 1, it can be seen that the total remittances in ASEAN region are increasing every year. In the period of research from 1984 to 2016, there was an increase. Starting from 1984 to 1997, the increase of remittances was relatively small and when compared to unemployment data there was an almost stable change until 1992 where a fairly rapid increase occurred until 1994, and then dropped back in 1995. In 1998, remittances increased by a large amount then sloping to fall in 2004; while in this period unemployment continued to increase until it reached its highest point in 2005 . At its peak in 2005, remittances also rose in line with unemployment. Furthermore, in 2005, data on remittance and unemployment research showed a decline until 2009; unemployment rose in 2010 and fell back to the end of the research period with remittances that tended to go up and down with relatively small changes.

Some empirical studies from various literature are needed to support this research and made into a summary form as shown in
Table 1

The empirical results above are the results of research carried out by several researchers with different backgrounds but refer to agreed-upon theoretical principles. These theories include the literature that reviews several theories relating to unemployment, such as the relationship between GDP (Gross Domestic Product) and unemployment. This relationship is known as Okun's law or Arthur Okun's finding. Okun's Law concept is based on US GDP data observation. It explains that the unemployment rate has a negative relationship with real GDP (Mankiw, 2010; Samuelson \& Nordhaus, 2004). Thus, referring to Okun's research (empirical evidence), there is a negative relationship between the rate of economic growth and unemployment. However, Mankiw (2010) in a book entitled "Macroeconomics" explained that Okun's Law occurred in the short term. In the long term, there are other things that affect GDP growth, especially technology. In addition, there will be a higher standard of living from one generation to another and there is no proven correlation with the unemployment rate.

Economic growth or GDP is one of the variables that determine the fluctuating number of unemployment in a country, where one variable that can increase economic growth and alleviate unemployment is an investment. Keynes in his book entitled The General Theory of Employment, Interest and Money explains the relationship between investment and the unemployment rate. Keynes's core idea is that the point of equilibrium of an economy occurs when aggregate demand equals aggregate expenditure, where unemployment can occur if aggregate demand is smaller than expenditure aggregate so that the longterm output will not absorb by consumers and will result in unemployment. One factor that drives aggregate demand is investment demand (Froyen, 2009).

Drinkwater, Levine, \& Lotti (2003) conducted a study that departed from the concept of remittance which has the opposite effect. First, remittances can have an impact on increasing unemployment. Second, remittances can also increase investment and ultimately reduce unemployment. If the effect of the second condition is greater than the first one, then the remittance will have an effect on reducing the average unemployment rate. The data used were panels from 20 countries from 1970 to 2000 . The data were regressed 
Table 1

Summary of Empirical Study Literatures for the Research

\begin{tabular}{|c|c|c|c|}
\hline No & Research of & Method & Result \\
\hline 1 & $\begin{array}{l}\text { Drinkwater, } \\
\text { Levine, \& Lotti } \\
\text { (2003) }\end{array}$ & Fixed Effect method & $\begin{array}{l}\text { Remittance has a small and insignificant effect on } \\
\text { the unemployment rate. Conversely, remittances } \\
\text { have a positive and significant impact on investment } \\
\text { which will ultimately have an effect on decreasing the } \\
\text { unemployment. }\end{array}$ \\
\hline 2 & $\begin{array}{l}\text { Driver \& } \\
\text { Muñoz- } \\
\text { Bugarin } \\
(2010)\end{array}$ & $\begin{array}{l}\text { - } \text { Cointegration } \\
\text { test } \\
\text { - } \text { Fixed Effect data } \\
\text { panel }\end{array}$ & $\begin{array}{l}\text { - In the long term, the share of labor in United Kingdom } \\
\text { has been decreased against investment capital. } \\
\text { - It is proven that investment has a negative and } \\
\text { significant relationship to the share of labor or is } \\
\text { related to unemployment in countries in Europe. }\end{array}$ \\
\hline 3 & $\begin{array}{l}\text { Eita \& } \\
\text { Ashipala } \\
(2010)\end{array}$ & $\begin{array}{l}\text { - } \text { ADF unit root } \\
\text { test } \\
\text { - Long-run } \\
\text { regression } \\
\text { results } \\
\text { - Error correction } \\
\text { model results }\end{array}$ & $\begin{array}{l}\text { - The increased cost of labor would increase } \\
\text { unemployment } \\
\text { - There is a negative relationship between the level of } \\
\text { participation and investment } \\
\text { - There is a long-term relationship between } \\
\text { unemployment and control variables including } \\
\text { investment }\end{array}$ \\
\hline
\end{tabular}

4 Aghion \& Search model Howitt (1994) of equilibrium unemployment

5 León-Ledesma - Fixed Effect \& Piracha - Generalized (2004) Moment of Method

6 Imoisi, Descriptive Olatunji, \& Ubi statistics (2013)

7 Catrinescu, LeonLedesma, Piracha, \& Quillin (2009)

8 Fanti \& Manfredi (2003)

9 Adams Jr \& Page (2005)
- Fixed Effect

- Generalized Moment of Method

Solovian growth model with nonmarket-clearing real wages and endogenous fertility.

Fixed Effect method

Every increase in capital generates an increase in employment and a decrease in the average balance of unemployment. This is in accordance with the theory of the benefits of capital.

Remittance has a positive effect on productivity and labor directly or indirectly through investment.

Recommendations for countries like Namibia (Least Developed Country): one thing that must be studied and developed is investment in human resources. This is related to several severe conditions and challenges that Namibia must face as a least developed country, including high population growth which encourages the creation of high employment opportunities. If this problem is unresolved, unemployment will be higher.

Supporting the view which states that remittances have a positive impact on productivity and employment both directly and indirectly through their influence on investment.

The effect of unemployment is doubled (through its influence on the population) on economic growth: it can be positive or negative depending on the relative level of childcare costs of workers and unemployed people, and on the unemployment benefit level. Thus, an increase in unemployment benefits - as happened in recent years in many countries such as France and Spain - can cause economic fluctuations and widespread demonstrations and influence on the positive effects of unemployment on economic growth.

International migration and remittance have a significant effect on reducing the depth of difference and poverty in developing countries. By using other factors, the results show that on the average of $10 \%$ increase in the immigrant population share in a country will reduce the share of domestic population who stay at $2.1 \%$ or less than $\$ 1.00$ per person per day. Also with other factors, if international remittances increase by $10 \%$ per capita, it can reduce the share of the poor by $3.5 \%$. 
10 Siddique, Selvanathan, \& Selvanathan (2012)

11 Shera \& Meyer Random Effect (2013)
Granger Causality test method
The results show that remittances have not proven to have an influence on economic growth in Bangladesh. There is no causal relationship between remittances and economic growth in India, but there is evidence of a causal relationship between remittances and economic growth in Sri Lanka.

The result shows that remittances have a positive impact on economic growth (GDP per capita) which ultimately involves unemployment. using the Fixed Effect model. The result is remittances have a small but insignificant effect on the unemployment rate. Conversely, remittances have a positive and significant impact on investment which will ultimately have an effect on decreasing unemployment.

Driver \& Muñoz-bugarin (2010) tried to prove whether the share of labor increase with the increasing investment. The research began with the hypothesis that additional investment could decline unemployment. It is assumed that with additional investment the labor absorption will increase towards investment. The data used is data manufacture UK (United Kingdom) with time series from 1985 to 2007 in quarter. The variables used are capital investment, real unit labor costs, and index of capacity utilization. The method used is the cointegration test and Fixed Effect data panel. The result is that in the long term, the share of labor in the United Kingdom has decreased against capital investment. Driver \& Muñozbugarin (2010) conducted a second analysis using Europe panel data that consistently existed from 1993-2006. The data showed that seven countries have complete data based on the year. The method used is Fixed Effect and Random Effect using 1 period lag. Model variables are in the form of logarithms to get elasticity results. The result proved that investment has a negative and significant relationship to the share of labor.

Eita \& Ashipala (2010) found that inflation in Namibia has a negative relationship with the unemployment rate as explained in the Phillips curve with the data used from 1971 - 2007. As a result, the increased costs of labor could increase unemployment, so that flexibility was needed for wage changes. Labor and trade unions must be able to reduce the effects of demand for increased wages and can help reduce the unemployment rate. Furthermore, Eita \& Ashipala (2010) also proved the existence of a negative relationship between unemployment and investment. The investment must be able to create jobs for unemployed people. This study also conducts a cointegration test to prove whether there is a long-term relationship between unemployment and its control variables. As a result, there is a long-term relationship between unemployment and control variables, including investment.

Research by Aghion \& Howitt (1994) found and compared two influences of growth and unemployment. First, the influence of capitalization where every increase in capital results in increased employment and decreases the average balance of unemployment. Leónledesma \& Piracha (2004) found that the impact of remittances on unemployment in Central and Eastern Europe (CEE) depended on productivity and investment growth. The study used productivity equations in 11 transition countries during the period of 1990 to 1999 . By this equation, it was proven that support for remittances had a positive effect on productivity and labor directly or indirectly through investment.

Research by Imoisi, Olatunji, \& Ubi (2013) provides recommendations to countries such as Namibia (Least Developed Country) that one that must be studied and developed is investment in human resources. This is related to several severe conditions and challenges that Namibia must face as a Least Developed Country, including high population growth which encourages the creation of high employment opportunities. If this problem is unresolved, the unemployment will be higher

Research by Catrinescu, Leonledesma, Piracha, \& Quillin(2009) reviewing the relative relationship of international migration remittance contributions towards the continuity/sustainability of economic development. While the official remittance record for State development has increased in the last decade, this research has no requirement that remittances have positive or negative results on long-term growth

Research by Fanti \& Manfredi (2003) found the doubled effect of unemployment (through its influence on the population) on 
economic growth: it can be positive or negative depending on the relative level of childcare costs of workers and unemployed people, and on the unemployment benefit level. It argues that the increase of unemployment benefits occurred in many countries, such as France and Spain, can be an example of positive influence of economic fluctuations on unemployment in economic growth.

Research by Adams Jr \& Page (2005) show that international migration and remittance have a significant effect on reducing the depth of difference and poverty in developing countries. By using other factors, the results show that on the average of $10 \%$ increase in the immigrant population share in a country will reduce the share of domestic population who stay at $2.1 \%$ or less than $\$ 1.00$ per person per day. Also with other factors, if international remittances increase by $10 \%$ per capita, it can reduce the share of the poor by $3.5 \%$.

Research by Siddique, Selvanathan, \& Selvanathan (2012) attempted to explain the relationship between remittances and economic growth in only three countries of Bangladesh, India, dan Sri Lanka. The data used is a panel of 25 years. The method used is Granger Causality in the VAR framework. The result is not proven that remittances have an effect on economic growth in Bangladesh. There is no causal relationship between remittances and economic growth in India, but finally, there is evidence that a causal relationship between remittances and economic growth exists in Sri Lanka. Furthermore, Siddique et al. linked these results to policies relating to access to financial institutions, gender issues, policies, investments, savings schemes, and promotion and education.

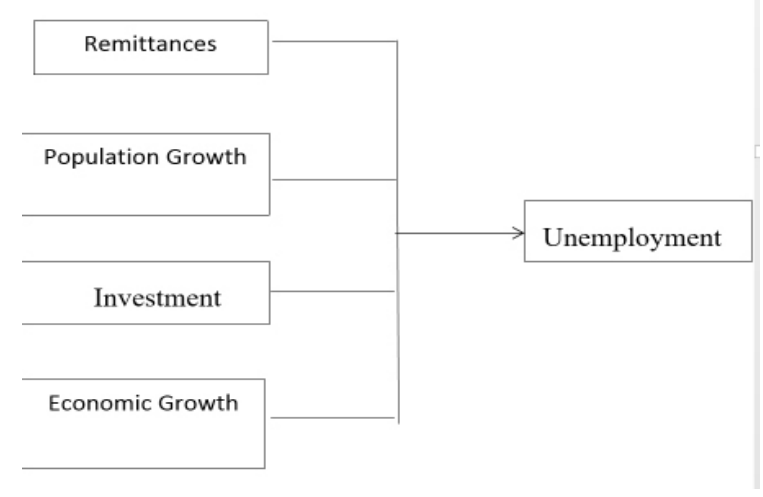

Figure 2. Framework of Research Research Methodology

Shera \& Meyer (2013) studied the impact of remittances on economic growth using data panel of 21 developing countries from 1992 to 2012. The method used is econometric regression with an estimated random effect model. The result is that remittances have a positive impact on economic growth (GDP per capita). Based on the introduction, objectives, theoretical assistance, and empirical studies, a framework can be made as shown in figure 2 .

This study discusses the effect of remittances, population growth, investment, and economic growth on unemployment in Indonesia. The analytical method used is a statistical and descriptive analysis with an econometric approach using Stata software. The estimation method of Ordinary Least Square (OLS) is used to analyze the effect of remittance variables, population growth, investment, and economic growth on unemployment. The data treatment included testing of classical assumptions, such as autocorrelation tests (using Durbin Watson method), and heteroscedasticity tests (using the White Heteroscedasticity test).

The data used in this study is secondary data with annual time series of 33 years with a period of 1984-2016. The research period was chosen because of the high increased number of unemployed people and remittance that tended to be stable in that period of time. The data obtained from the World Bank website which displayed various data indicators from various countries, including the main data used in this research, namely remittances.

This study uses research models of Drinkwater et al., (2003), namely the effect of remittances on unemployment model. This study adds free variables that are considered to influence unemployment, which are population growth, investment, and economic growth written in the model below:

unemployment $_{t}=\beta_{0}+\beta_{1} r$ 萃mittance ${ }_{t}+\beta_{2}$ lsop $_{t}+$

$$
\beta_{3} \operatorname{linv}_{t}+\beta_{4} g d p_{-} \text {growth }_{t}+u_{t}
$$

Description:

unemployment $t_{t}$ : unemployment rate

remittance $_{t} \quad$ : remittance

Ipoptot $_{t} \quad$ : population logarithm

linv $_{t} \quad$ : investment logarithm

gdp_growth $\mathrm{t}_{\mathrm{t}}$ : GDP growth

$\mathrm{u}_{\mathrm{t}} \quad$ : error term

The variable of unemployment rate is used in the form of a percentage of people who have already in their working age but do not have employment to the Indonesian population. Next is the remittance variable which is the ratio of data from personal remittances to GDP. Personal money in question can be in the form of personal 
transfers or employee compensation. The population growth variable as the percentage increase in population per year is also added. Furthermore, the investment variable is added which is the total value of total fixed assets acquired by the business, government, and household sectors. Then the variable is modified into a logarithmic form in order to facilitate the interpretation of the regression results. The last one is using economic growth variable. These variables are obtained based on the percentage of annual growth of constant Indonesian GDP.

There are variables of logarithmic forms in the independent, such as population logarithmic variables and investment logarithms. The interpretation of these variables coefficients is different from the interpretation of variables that are linear/nonlogarithmic. If using logarithms, the way of interpreting the beta would be that every delta (increase/decrease) of $1 \%$ in that variable will increase/decrease the dependent variable by beta/100 or its antilogarithm (Wooldridge, 2012). In the table 2 explains the research variable operationalization.

Classical Assumption Test consists of multicollinearity test and heteroscedasticity test. Multicollinearity test is conducted to test whether there is a strong correlation between independent variables in the model. That strong correlation is called having a multicollinearity problem. Heteroscedasticity test is carried out to ensure that the model built is homoscedasticity. Homoscedasticity means the variance of unobserved or term errors is constant in each segment of the population. Problems of Autocorrelation occurs when in a linear regression model there is a correlation between errors in period $t$ and errors in period $\mathrm{t}-1$.

\section{Results And Discussion}

This section will discuss the results of model testing using the OLS method, the classical assumptions testing that has already attached, and economic analysis to understand the relationship between the results of research and existing theories.

\section{Statistical Analysis}

This section displays the statistical results of all variables used in the study. It can be seen that Indonesia's average unemployment rate was $5.85 \%$ from 1984 to 2016. Indonesia has a fairly high economic growth. It is proven that on average Indonesia's economic growth is $5.04 \%$ since 1984. However, Indonesia's population growth was also quite high which amounted to $19.16 \%$. It means there will be more problems as the population increases, as can see in Table 3.

This summary of statistics was processed from the data that would be regressed. All data came from 1984 to 2016 . The average Indonesian poverty rate from 1984 to 2016

Table 2

The Research Variable Operationalisation

\begin{tabular}{|c|c|c|c|}
\hline Variable & Definition & Unit & Symbol \\
\hline Unemployment rate & $\begin{array}{l}\text { The unemployment rate is taken from the } \\
\text { growth of number of people who have already } \\
\text { in their working age but do not have jobs }\end{array}$ & $\%$ & Unemployment \\
\hline Remittance & $\begin{array}{l}\text { The form of ratio of personal remittances } \\
\text { consists of personal transfers and employee } \\
\text { compensation. }\end{array}$ & $\%$ & Remittance \\
\hline $\begin{array}{l}\text { Population growth } \\
\text { (logarithm) }\end{array}$ & The rate of population growth & $\%$ & Lpoptot \\
\hline $\begin{array}{l}\text { Investment } \\
\text { (logarithm) }\end{array}$ & $\begin{array}{l}\text { The algorithm form of the total value of fixed } \\
\text { assets acquired by the business, government, } \\
\text { and household sectors }\end{array}$ & $\%$ & Linv \\
\hline Economic growth & $\begin{array}{l}\text { Percentage of growth of total market value } \\
\text { of all goods and services in the economy in a } \\
\text { given period of time }\end{array}$ & $\%$ & g_gdp \\
\hline
\end{tabular}


MIMBAR, Vol. 35 No. $1^{\text {st }}(2019)$

Table 3

Summary of Statistics

\begin{tabular}{llllll}
\hline Variable & Obs & Mean & Std. Dev. & Min & Max \\
\hline Unemployment & 33 & 5.850606 & 2.733338 & 1.52 & 11.2 \\
Remittance & 33 & 0.62577 & 0.468889 & 0.058663 & 1.780592 \\
g_gdp & 33 & 5.045485 & 3.58863 & -13.1267 & 8.220007 \\
linv & 33 & 24.85714 & 0.968362 & 23.59485 & 26.439 \\
Ipoptot & 33 & 19.16134 & 0.142484 & 18.90036 & 19.38047 \\
\hline
\end{tabular}

Table 4

Correlation Coefficients

\begin{tabular}{llllll}
\hline & Unemployment & Remittance & g_gdp & linv & Ipoptot \\
\hline Unemployment & 1 & & & & \\
Remittance & 0.7982 & 1 & & & \\
g_gdp & -0.0736 & -0.1981 & 1 & & \\
linv & 0.4476 & 0.6343 & 0.1871 & 1 & \\
Ipoptot & 0.7051 & 0.8109 & -0.0476 & 0.9019 & 1 \\
\hline
\end{tabular}

Table 5 Variance Inflation Factors ( VIF )

\begin{tabular}{lll}
\hline Variable & VIF & 1 VIF \\
\hline & & \\
$\mathrm{t}$ & 302.31 & 0.003308 \\
Ipoptot & 252.74 & 0.003957 \\
linv & 11.3 & 0.088507 \\
remittance & 3.54 & 0.282484 \\
g_gdp & 1.46 & 0.686287 \\
& & \\
Mean of VIF & 114.27 & \\
\hline
\end{tabular}

was $5.85 \%$. Remittances (remittance ratio to GDP) had an average of 0.62 , while the average GDP growth was $5.04 \%$.

\section{Multicollinearity Test}

The following are the results of multicollinearity test using correlation coefficients (in Table 4 and Tabel 5).

The result shows that the linv and Ipoptot variables have a very strong correlation (90.19\%). But it can be ignored because it has no effect on the BLUE estimator (Wooldridge, 2012). However, estimators that have multicollinearity problems will have greater variance.

\section{Heteroscedasticity Test}

The following heteroscedasticity test uses the White Test:

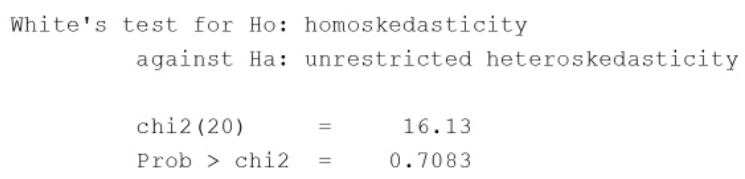

Based on the result of heteroscedasticity test, value of prob >chi2 (0.7083) > a (5\%), then Ho cannot be rejected. Thus, it can be concluded that there is no problem of heteroscedasticity in the model. 


\section{Autocorrelation Test}

The following Autocorrelation Test uses the Durbin Alternative:

Durbin's alternative test for autocorrelation

\begin{tabular}{c|ccc}
\hline $\operatorname{lags}(p)$ & chi2 & df & Prob $>$ chi2 \\
\hline 1 & 3.648 & 1 & 0.0561 \\
\hline
\end{tabular}

H0: no serial correlation

The result shows that value of prob $>$ chi2 $(0.0561)>a(5 \%)$, then Ho cannot be rejected. Thus, it can be concluded that there is no problem of autocorrelation in the model.

\section{Estimated Results}

The following OLS estimation results are free from classic assumption problems by adding $t$ variable (trend).

Table 6 LS Estimated Results

\begin{tabular}{ll}
\hline VARIABLE & UNEMPLOYMENT \\
& \\
\hline Remittance & $3.005^{* * *}$ \\
& $(0.897)$ \\
gdp_growth & $0.206 * *$ \\
& $(0.0752)$ \\
linv & $-2.592^{* * *}$ \\
& $(0.776)$ \\
Ipop & $60.57 * *$ \\
& $(24.93)$ \\
t & -0.575 \\
& $(0.402)$ \\
Constant & $-1,083^{*} *$ \\
& $(478.1)$ \\
& \\
Observations & 33 \\
\hline
\end{tabular}

Standard errors in parentheses *** $\mathrm{p}<0.01, * * \mathrm{p}<0.05, * \mathrm{p}<0.1$

Data in table 6 shows that the determination coefficient value is 0.820 which states that variations of all independent variables in the model (remittance, economic growth, investment, and population growth) are able to explain the variation of the dependent variable by $82 \%$, while the remaining $18 \%$ is explained by other variables outside the model.
Whereas the result of other independent variables is explained in the following section.

\section{Remittance}

The estimation results also show the results of remittance coefficient (remittance ratio to GDP) of 3,005 . It means that every $1 \%$ point increase in remittances will increase unemployment by $0.003 \%$ points, ceteris paribus. The more workers working abroad (equal to more remittances) have the potential to increase unemployment in the country, which means:

Consumption. Many workers use their income (remittances) to fulfill the needs of their families in Indonesia, so that consumption increases. In addition to fulfilling family consumption, many workers also spend their money on self-consumption at work or abroad. These results contrast with expectations of an increase in economic growth obtained from service sector revenues. The income (remittance results) should be able to alleviate unemployment because it can be used to increase domestic-available capital and then the capital becomes an investment that can eventually reduce the number of unemployed people in the country.

Data used in this study are remittance data or the amount of earnings people received from working abroad and not the number of workers who work abroad so that it (indirectly) does not reduce the number of unemployment. Results of the 34-year study prove that sending workers abroad does not reduce the number of unemployed people in Indonesia. What actually happens is that there are problems with the recipient countries because Indonesian workers are sent legally and illegally which means it would be hard to record the total workforce in certainty. The government should make the workers understand that their income from working abroad can be useful in the long term by way of saving as capital that will be used for investment. The government must equip prospective workers with more skills so that they can get even more income.

Remittances in Indonesia tend to increase unemployment compared to increase in the value of the investment. The results of this study are different from Drinkwater, Levine, \& Lotti (2003) which state that indeed remittances have two effects, but if the effect on investment is greater then remittances it can be said to encourage a decrease in the unemployment rate through investment. But 
the results are different for Indonesia.

\section{Economic Growth}

Economic growth has a significant positive effect, namely, if economic growth rises by $1 \%$, unemployment will increase by $0.020 \%$ points, which is caused by:

Inequality in economic growth between developed and developing regions in Indonesia causes employment opportunities concentrated in the developed region because of investment increases; while developing regions lag behind in employment opportunities because of limited technology or different expertise needed based on the society's conditions.

The result of this study indicates a discrepancy with the theory because if there is an increase in economic growth then unemployment must be decreased because it will open up new opportunities for job seekers. This discrepancy can occur if economic growth cannot reach the whole employment of all workforce due to their diverse expertise which is not in accordance with the employment needs. Okun's law explains that the unemployment rate has a negative relationship with real GDP (Mankiw, 2010; Samuelson \& Nordhaus, 2004). This gives information that based on Okun's research (empirical evidence), there is a negative relationship between the level of economic growth and unemployment. However, Mankiw (2010) in his book entitled "Macroeconomics" explains that Okun's Law occurs in the short term. In the long term, there are other things that affect GDP growth, especially technology. Another thing is a higher standard of living from one generation to another and proves there is no correlation with the unemployment rate.

\section{Investment}

Investment has a significant negative effect on unemployment, namely, if the investment rises by $1 \%$, unemployment will decrease by 0.025 . The results of the study are in accordance with the theory because the higher or greater the amount of investment will provide broad employment opportunities for unemployment.

In this study, investment has an influence as indicated by the estimation results in accordance with Keynesian economic theory stating that domestic investment has a negative relationship with the unemployment rate. Increased investment will drive the aggregate demand curve. With the increasing investment, companies can expand their business to ultimately increasing the need for labor and reducing the average unemployment rate. In addition, the results of this study are consistent with the empirical results of Driver \& Muñoz-bugarin (2010) who tried to prove whether the share of labor increases with the increase of investment. The study departs from the hypothesis that additional investment can encourage a decrease in unemployment. Furthermore, Eita \& Ashipala (2010) also proved the existence of a negative relationship between the unemployment rate and investment. The investment must be able to encourage job creation for those who are unemployed.

\section{Population}

Population growth has a significant positive effect on unemployment, namely, if the population rises by $1 \%$, unemployment will increase by $0.605 \%$ points.

The results of the study did show the appropriate results, but when viewed from the data, additional populations of newly entered or newborn citizens should not be included in the data because the population most associated with unemployment is those who are just entering the workforce.

This study still needs to be tested with data of the ready to work population. Thus, the before entering the workforce population must be separated from the is ready-to-work population. It can be seen from the data that population growth during the study period showed the highest growth rate of $19.16 \%$ or exceeded other variables, and this was very closely related to unemployment. The results of this study are in line with the research results by Imoisi, Olatunji, \& Ubi (2013), which among others, stating that high population growth demands the creation of high employment opportunities. If this problem is unresolved, the unemployment rate will be even higher.

Population growth can be a negative burden if it is not managed and utilized well, but if it is handled properly it can be a positive production factor in economic development, as stated in the research by Imoisi, Olatunji, \& Ubi (2013) which provides recommendations to countries such as Namibia (Least Developed Country) to study and develop one important thing, that is investing in human resources. This is related to several severe conditions and challenges Namibia must face as a least developed country, including high population growth which demands high employment creation. If this is unresolved, the unemployment rate will be higher.

\section{Conclusions}

This study tries to look at the influences of remittances, population growth, investment, and economic growth on unemployment in 
Indonesia. The results show that remittances, population growth, and economic growth have a significant positive effect on unemployment while investment has a significant negative effect on unemployment. Remittances in Indonesia, from the estimation results, has the results of the remittance coefficient (remittance ratio to GDP). It means that every increase in remittance will increase unemployment, ceteris paribus. Remittances in Indonesia tend to increase unemployment compared to increase the value of the investment. Economic growth has a significant positive effect, namely, if economic growth rises, unemployment will increase. Indonesia's economic growth has not been able to overcome unemployment because it has not been evenly distributed in each region in Indonesia. It occurs due to the high population increase and has been confirmed in the estimation results that are proven to increase unemployment. if the population increases. Investment has a significant negative effect on unemployment, namely, if the investment rises, unemployment will decrease. The results of the study have shown compatibility with the theory because the higher or greater the amount of investment will provide broader employment opportunities for unemployment. Population growth has a significant positive effect on unemployment, namely, if the population rises, unemployment will increase, where the population data used is the entire population instead of only the workforce population.

In the end, the problem of unemployment cannot be resolved partially but should encourage all possible variables together. In theory, remittances can increase the capital which will encourage investment so that it can encourage job creation and eventually reducing unemployment. But in reality, the positive impact of those investments is still lower than the direct impact of remittances on increasing unemployment. The results of this study are expected to find factors that cause unemployment and factors that can help overcome unemployment. This research can be further continued with other variables through the use of data on the number of workers per person equipped with the expertise of each worker who works abroad, rather than just their income. Other data that can be added is the separation of the population from those who have entered the workforce and those who have not entered the workforce yet.

\section{References}

Adams Jr, R. H., \& Page, J. (2005). Do international migration and remittances reduce poverty in developing countries? World Development, 33(10), 1645-1669.

Aghion, P., \& Howitt, P. (1994). Growth and Unemployment, 61(3), 477-494.

Catrinescu, N., Leon-ledesma, M., Piracha, M., \& Quillin, B. (2009). Remittances, Institutions, and Economic Growth. World Development, 37(1), 81-92.

Drinkwater, S., Levine, P., \& Lotti, E. (2003). The Labour Market Effects of Remittances, $1-45$.

Driver, C., \& Muñoz-bugarin, J. (2010). Capital investment and unemployment in Europe : Neutrality or not? Journal of Macroeconomics, 32(1), 492-496.

Eita, J. H., \& Ashipala, J. M. (2010). Determinants of Unemployment in Namibia, 5(10), 92-104.

Fanti, L., \& Manfredi, P. (2003). Population, Unemployment And Economic Growth Cycles : A Further Explanatory Perspective, 3, 179-207.

Froyen, R. (2009). Macroeconomics : Theories and Policies. (E. Svendsen, Ed.) (9th ed.). Pearson.

Imoisi, A. I., Olatunji, L. M., \& Ubi, A. I. P. (2013). Population and Its Impact on Level of Unemployment in Least Developed Countries: An Appraisal of the Nigerian Economy. European Social Sciences Research Journal, 277-291.

Jajang, Saefuddin, A., Mangku, I. W., \& Siregar, H. (2013). Analisis Kemiskinan menggunakan Model Panel Spasial Statik. Mimbar, 29(2), 195-203.

Lal, I., \& Muhammad, S. D. (2010). Test of Okun' s Law in Some Asian Countries Co-Integration Approach, 40(1), 73-80.

León-ledesma, M., \& Piracha, M. (2004). International Migration and the Role of Remittances in Eastern Europe, 42(4).

Mankiw, N. G. (2010). Macroeconomics (7th ed.). New York: Worth Publishers.

Samuelson, P. A., \& Nordhaus, W. D. (2004). Macroeconomics. McGraw-Hill.

Shera, A., \& Meyer, D. (2013). Remittances and their impact on Economic Growth. Social and Management Sciences, 211, 3-19.

Siddique, A., Selvanathan, E. A., \& Selvanathan, S. (2012). Remittances and economic growth: empirical evidence from Bangladesh, India and Sri Lanka. Journal of Development Studies, 48(8), 1045-1062.

Wooldridge, J. M. (2012). Introductory Econometrics: A Modern Approach (5th ed.). Cengage Learning. 